\title{
Study of Tungsten Phosphate Glasses Containing $\mathrm{Fe}_{2} \mathrm{O}_{3}$
}

\author{
Hicham Es-Soufi ${ }^{*}$, Lahcen Bih ${ }^{1,2}$, Meyrem Benzineb ${ }^{1}$ \\ ${ }^{1}$ Equipe de Physico-Chimie de la Matière Condensée, PCMC, Faculté des Sciences de Meknès, Université Moulay Ismail, \\ Meknès, Morocco \\ ${ }^{2}$ Département matériaux et procédés, ENSAM Meknès, Université Moulay Ismail, Meknès, Morocco \\ Email: ^hichamessoufi@gmail.com
}

How to cite this paper: Es-Soufi, H., Bih, L. and Benzineb, M. (2019) Study of Tungsten Phosphate Glasses Containing $\mathrm{Fe}_{2} \mathrm{O}_{3}$. New Journal of Glass and Ceramics, 9, 33-49. https://doi.org/10.4236/njgc.2019.93004

Received: March 31, 2019

Accepted: July 6, 2019

Published: July 9, 2019

Copyright (C) 2019 by author(s) and Scientific Research Publishing Inc. This work is licensed under the Creative Commons Attribution International License (CC BY 4.0).

http://creativecommons.org/licenses/by/4.0/

\begin{abstract}
Glasses of the compositions $20 \mathrm{Li}_{2} \mathrm{O}-(50-\mathrm{x}) \mathrm{Li}_{2} \mathrm{WO}_{4}-\mathrm{xFe}_{2} \mathrm{O}_{3}-30 \mathrm{P}_{2} \mathrm{O}_{5}$ where $(\mathrm{x}$ $=0,1,5,8,10,15 \mathrm{~mol} \%)$ were elaborated by the melt-quenching route. Synthesized glasses are characterized using X-ray diffraction (XRD), Fourier Transform Infrared Spectroscopy (FTIR), differential scanning calorimetric (DSC), and density determination. The XRD patterns confirmed the amorphous nature of samples, and IR spectra showed the structural groups and highlight the depolymerization of phosphate network with the introduction of iron oxide. It is found that the structural unit $\mathrm{Q}^{2}$ converts to $\mathrm{Q}^{1}$ and $\mathrm{Q}^{0}$ as $\mathrm{Fe}_{2} \mathrm{O}_{3}$ replaces $\mathrm{Li}_{2} \mathrm{WO}_{4}$. Chemical durability tests on the glasses have shown that the compositions containing pyrophosphate $\left(\mathrm{Q}^{1}\right)$ and orthophosphate $\left(\mathrm{Q}^{0}\right)$ units are more water-resist. The electrical conductivity measurements were performed by complex impedance spectroscopy in the frequency range of $20-10^{6} \mathrm{~Hz}$ at various temperatures from ambient to $400^{\circ} \mathrm{C}$. It is found that the conductivity is activated thermally and follows an Arrhenius law. The obtained electrical data were analyzed by the modulus formalism and dielectric formalism. The determined asymmetric nature of $M^{\prime \prime} / M_{\max }^{\prime \prime}$ spectra suggested that the relaxation behavior is non-Debye and characterized by the stretched exponent parameter $\beta<1$.
\end{abstract}

\section{Keywords}

Phosphate, Glasses, Thermal Analysis, Structure, Electrical Conductivity

\section{Introduction}

Phosphate glasses are one of the good hosts of several transition metal oxides (TMO) which show different valence states. The valence state of such metal de- 
pends on the content and the properties of the other components of the glasses [1] [2] [3]. The transition metal ion can locate in the network either in the substitution or interstitial positions. When the ions take the substitution position, it is able to crosslink between the glass former and modifier. But, in the case where the ions locate in the interstitial positions, it can link to non-bridging oxygen (NBO) [4]. Transition metals are used as activators in advanced technologies such as phosphors, lasers, solar energy converters and in a number of electronic devices. Recently, the transition metal oxides doped alkali phosphate glasses have been the subject of intensive investigation in view of their potential applications in various domains of modern technology [5]. The investigation of relationship between structure and properties is essential in material science. Alkali phosphates form good glasses over a wide range of composition. But, one of the major issues that limit the use of phosphate glasses is their poor chemical durability. The improvement of their chemical durability is often realized by the addition of some oxides such as $\mathrm{Al}_{2} \mathrm{O}_{3}, \mathrm{SnO}, \mathrm{Fe}_{2} \mathrm{O}_{3}$ [6]. Also, the addition of iron oxide to lead phosphate improves the chemical durability of the glass without substantial change in the physical properties [7]. In addition, iron phosphate glasses have attracted much attention owing to their high chemical durability, wide compositional flexibility and low melting temperature [8] [9]. These glasses are known for their high chemical durability and for their application in vitrifying nuclear waste [10] [11]. Owing to the insertion of iron in the phosphate matrix, the easily hydrolysable P-O-P bridging links have been replaced by the water-resist Fe-O-P linkages thereby providing these glasses with excellent chemical durability [12] [13]. In this context, S. Nakata et al. have reported that the addition of divalent $\mathrm{Fe}^{2+}$ into $\mathrm{NaPO}_{3}$ broke the P-O-P bonds and forms water-resist Fe-O-P linkages in $\mathrm{xFeO}-(100-\mathrm{x}) \mathrm{NaPO}_{3}$ glasses [14]. Also, $\mathrm{Y} . \mathrm{M}$. Moustafa et al. reported that the increasing $\mathrm{Fe}_{2} \mathrm{O}_{3}$ in the $\mathrm{xFe}_{2} \mathrm{O}_{3}-(100-\mathrm{x}) \mathrm{P}_{2} \mathrm{O}_{5}$ system leads to the formation of P-O-Fe ${ }^{2+}$ and $\mathrm{P}-\mathrm{O}-\mathrm{Fe}^{3+}$ bonds [15].

Recently, we have studied the effect of substitution of $\mathrm{Li}_{2} \mathrm{WO}_{4}$ by $\mathrm{TiO}_{2}$ inside the $\mathrm{Li}_{2} \mathrm{O}-\mathrm{Li}_{2} \mathrm{WO}_{4}-\mathrm{TiO}_{2}-\mathrm{P}_{2} \mathrm{O}_{5}$ glasses [16]. In the present work our interest is focused on the investigation of the influence of the substitution of $\mathrm{Li}_{2} \mathrm{WO}_{4}$ by $\mathrm{Fe}_{2} \mathrm{O}_{3}$ with the glasses $20 \mathrm{Li}_{2} \mathrm{O}-(50-\mathrm{x}) \mathrm{Li}_{2} \mathrm{WO}_{4}-\mathrm{xFe}_{2} \mathrm{O}_{3}-30 \mathrm{P}_{2} \mathrm{O}_{5}$ where $(\mathrm{x}=0,1,5$, $8,10,15 \mathrm{~mol} \%)$. Some physical properties such as density, molar volume, glass transition temperature are studied. The structural approach of the glasses is realized by Infrared spectroscopy. The temperature and composition dependencies of their electrical properties are also investigated.

\section{Experimental Procedure}

The phosphate $20 \mathrm{Li}_{2} \mathrm{O}-(50-\mathrm{x}) \mathrm{Li}_{2} \mathrm{WO}_{4}-\mathrm{xFe}_{2} \mathrm{O}_{3}-30 \mathrm{P}_{2} \mathrm{O}_{5}(0 \leq \mathrm{x} \leq 15 \mathrm{~mol} \%)$ glasses were prepared from precursors purchased from Sigma-Aldrich. Powders of lithium carbonate $\left(\mathrm{Na}_{2} \mathrm{CO}_{3}\right)$, iron trioxide $\left(\mathrm{Fe}_{2} \mathrm{O}_{3}\right)$, lithium tungstate $\mathrm{Li}_{2} \mathrm{WO}_{4}$, and hydrogen ammonium phosphate $\left(\mathrm{NH}_{4} \mathrm{H}_{2} \mathrm{PO}_{4}\right)$ were weighed to get the required composition and ground in a mortar with pestle for $30 \mathrm{~min}$ to obtain 
homogenous compositions. Each mixture was heated in an electric furnace at $300^{\circ} \mathrm{C}$ and $600^{\circ} \mathrm{C}$ by placing them in an alumina crucible for several hours. Then, the temperature of the furnace is increased to attain the melt for about 30 $\min$ at $900^{\circ} \mathrm{C}$, the preparation temperature until a bubble free liquid was formed. The melt was then rapidly quenched by pouring it on to a stainless steel plate maintained at $T_{g}-20^{\circ} \mathrm{C}$ to avoid excess thermal shocks. The obtained glasses were annealed for $3 \mathrm{~h}$ at $300^{\circ} \mathrm{C}$ to relieve the mechanical strains. The glasses were placed in a desiccator before uses.

X-ray patterns of powdered samples were recorded using a Phillips D5000 diffractometer equipped with a $\mathrm{CuK}_{\alpha} \mathrm{X}$-ray source and a Ni filter $\left(\mathrm{K}_{\alpha}=1.54 \AA\right)$ at room temperature. The XRD data were recorded in $2 \theta$ range $\left(10^{\circ}-90^{\circ}\right)$ with 0.02 step width.

The density $(\rho)$ of glasses was measured at room temperature by the Archimedes method using diethyl orthophthalate as the suspension medium. The uncertainty of the measurements is estimated to be $\pm 0.01 \mathrm{~g} / \mathrm{cm}^{3}$. Molar volume $\left(V_{m}\right)$ of each glass is derived from the molar weight values $(M)$ and the density $\left(V_{m}=M / \rho\right)$. Oxygen packing density (OPD) of each glass was calculated from the density and composition using the formula $\mathrm{OPD}=100 C(\rho / M), C$ is the number of oxygens per formula unit.

The glass transition temperature $\left(T_{g}\right)$ and crystallization temperature $\left(T_{c}\right)$ of the prepared glasses, they are determinated from DSC curves, which have been obtained by using DSC 131 Evo analyser. The estimated error on the temperature is $\pm 4^{\circ} \mathrm{C}$. As type of, as the DSC curves depend of the particle size of ground glass batches which fixed about at $300 \mu \mathrm{m}$ Sieve in this study for all glasses. The amount of ground glass batches is about $40 \mathrm{mg}$ in nitrogen atmosphere at heating rate $10^{\circ} \mathrm{C} / \mathrm{min}$.

FTIR absorption spectra of the prepared glasses were collected at room temperature in the range $1400-400 \mathrm{~cm}^{-1}$ (wavenumber) using the Fourier Transform Infrared FTIR TENSOR27 Spectrometer. The measurement carried out by using the pellets. These pellets were prepared by mixing about $1 \mathrm{mg}$ of glass powder with $100 \mathrm{mg}$ of anhydrous $\mathrm{KBr}$.

The chemical durability tests are realized on the glasses which were cut in parallelepiped shapes. The block of glass was rinsed with acetone and then dried. Each sample of glass was placed in a bottle containing deionized water $(\mathrm{pH}=$ 6.8). The bottles were then suspended in a thermostat bath maintained at a temperature of $30^{\circ} \mathrm{C}$ for duration of 250 hours. All the experiments are done under the same conditions and the ratio $S / V(S$ : glass surface, $V$ : volume of the altering solution) is maintained at $0.04 \mathrm{~cm}^{-1}$. The mass change $(\Delta m)$ is determined as a function of time according to the equation: $\Delta m=\left(m_{0}-m_{t}\right) / A$, where: $m_{0}, m_{t}$ and $A$ are the initial mass, mass at specific time point and surface area of the specimen $\left(\mathrm{cm}^{2}\right)$, respectively. The $\mathrm{pH}$ values of the test solutions were measured by a $\mathrm{pH}$-meter.

Electrical measurements of the prepared glasses were performed by Imped- 
ance Spectroscopy (IS) Hewlett Packard Model 4284 A precision LCR. The amplitude of the DC signal applied across the sample was $0.5 \mathrm{~V}$. These glasses were ground to fine powder and made into pellets with $10 \mathrm{~mm}$ diameter and thickness of $1 \mathrm{~mm}$. The pellets were dried and coated with silver paint on either faces. The real and imaginary parts of complex impedance measurements were measured as a function of frequency $\left(20 \mathrm{~Hz}-10^{6} \mathrm{~Hz}\right)$ and temperature $(328 \mathrm{k}-627$ k).

\section{Results and Discussion}

\subsection{X-Ray Diffraction}

To ascertain the vitreous state of the prepared glasses we have first of all tested these samples by the X-ray diffraction (XRD) analysis. Figure 1 shows the XRD patterns of the studied samples. These patterns are free from peaks suggesting the absence of any crystalline phases inside the samples thereby confirming their amorphous state. All the glasses are colored except the composition $(x=0)$ which is colorless suggesting that the transition metal is in its high valence state $\left(\mathrm{W}^{6+}\right)$ in this composition.

\subsection{Density and Molar Volume}

Figure 2 illustrates the variations of the density and molar volume as a function of iron content $\left(\mathrm{Fe}_{2} \mathrm{O}_{3}\right.$ in mol \%). The addition of $\mathrm{Fe}_{2} \mathrm{O}_{3}$ on behalf of tungsten oxide decreases the density and increases the molar volume. The increase of $\mathrm{Fe}_{2} \mathrm{O}_{3}$ ratio results in an open glass structure with lower compaction. The density decreases from $4.18 \mathrm{~g} / \mathrm{cm}^{3}$ for $(\mathrm{x}=0)$ to $3.61 \mathrm{~g} / \mathrm{cm}^{3}$ for the glass $(\mathrm{x}=15)$. The experimental data of these parameters as listed in Table 1 . As in our previous

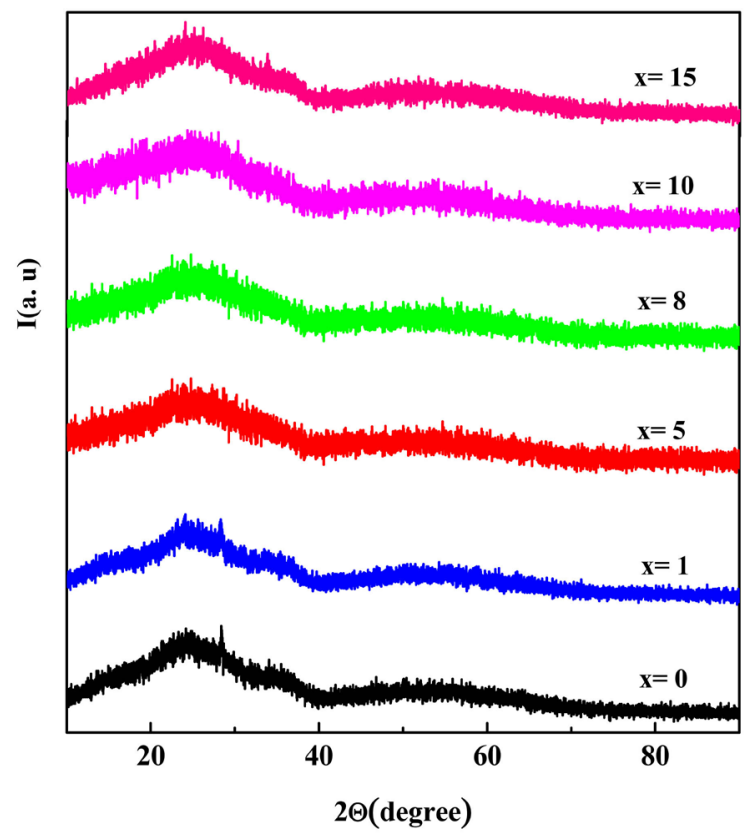

Figure 1. X-ray patterns of the $\mathrm{Li}_{2} \mathrm{O}-\mathrm{Li}_{2} \mathrm{OWO}_{4}-\mathrm{Fe}_{2} \mathrm{O}_{3}-\mathrm{P}_{2} \mathrm{O}_{5}$ glasses. 


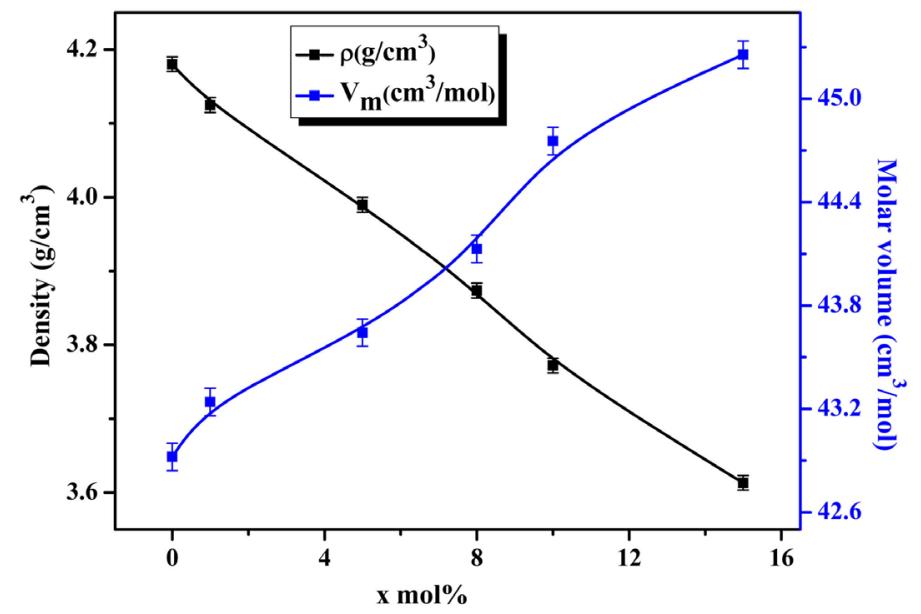

Figure 2. Composition dependence of the density and the molar volume for glasses.

Table 1. Some physical properties for the studied glasses.

\begin{tabular}{ccccccc}
\hline $\begin{array}{c}\mathrm{X} \\
(\mathrm{mol} \%)\end{array}$ & $\begin{array}{c}\text { Density } \\
\left(\mathrm{g} / \mathrm{cm}^{3}\right)\end{array}$ & $\begin{array}{c}\text { Molar volume } \\
\left(\mathrm{cm}^{3} / \mathrm{mol}\right)\end{array}$ & $\begin{array}{c}\text { OPD } \\
\text { (oxygen packing density) }\end{array}$ & $T_{g}\left({ }^{\circ} \mathrm{C}\right)$ & $T_{c 1}\left({ }^{\circ} \mathrm{C}\right)$ & $T_{c 2}$ \\
\hline 0 & 4.18 & 42.92 & 86.20 & 407 & 502 & - \\
1 & 4.12 & 43.24 & 85.38 & 420 & 532 & - \\
5 & 3.98 & 43.64 & 83.63 & 422 & 518 & - \\
8 & 3.87 & 44.13 & 82.03 & 425 & 508 & 550 \\
10 & 3.78 & 44.75 & 80.44 & 429 & 495 & 548 \\
15 & 3.61 & 45.26 & 78.44 & 432 & 498 & 552 \\
\hline
\end{tabular}

work [15], the decrease in density can be explained by the large difference in molecular weight between $\mathrm{Li}_{2} \mathrm{WO}_{4}(261.72 \mathrm{~g} / \mathrm{mol})$ and $\mathrm{Fe}_{2} \mathrm{O}_{3}(159.69 \mathrm{~g} / \mathrm{mol})$. The introduction of the lighter molecule in the glass instead of a heavier one leads to decrease the density. On the other hand, the increase of molar volume from $42.92 \mathrm{~cm}^{3} / \mathrm{mol}(\mathrm{x}=0)$ to $45.26 \mathrm{~cm}^{3} / \mathrm{mol}(\mathrm{x}=15)$ when $\mathrm{Fe}_{2} \mathrm{O}_{3}$ replaced $\mathrm{Li}_{2} \mathrm{WO}_{4}$ reveals either an increase of the interatomic spacing or the decrease of the strength constant of the bonds inside the glassy network. The increase of volume with (x) put forward that the interatomic spacing among the atoms of glass network increases when $\mathrm{Fe}_{2} \mathrm{O}_{3}$ ratio increases. Specially, the increase of the average length of $\mathrm{M}-\mathrm{O}(\mathrm{M}=\mathrm{P}, \mathrm{W}, \mathrm{Fe})$ bonds can explain the observed increase of $\left(V_{m}\right)$. This happens when some bridging oxygen $(\mathrm{BO})$ convert to non-bridging oxygen (NBO) in the glassy-matrix.

\subsection{DSC Analysis}

The DSC curves of the prepared glasses are shown in Figure 3. The endothermic peaks in DSC traces represent glass transition phenomena and the onset temperature of endothermic peak corresponds glass transition temperature $\left(T_{g}\right)$. An exothermic peak represents the crystallization occurring at the peak temperature $\left(T_{c}\right)$. The DSC curves of the glasses $(\mathrm{x}=0,1$ and 5$)$ are characterized by an 


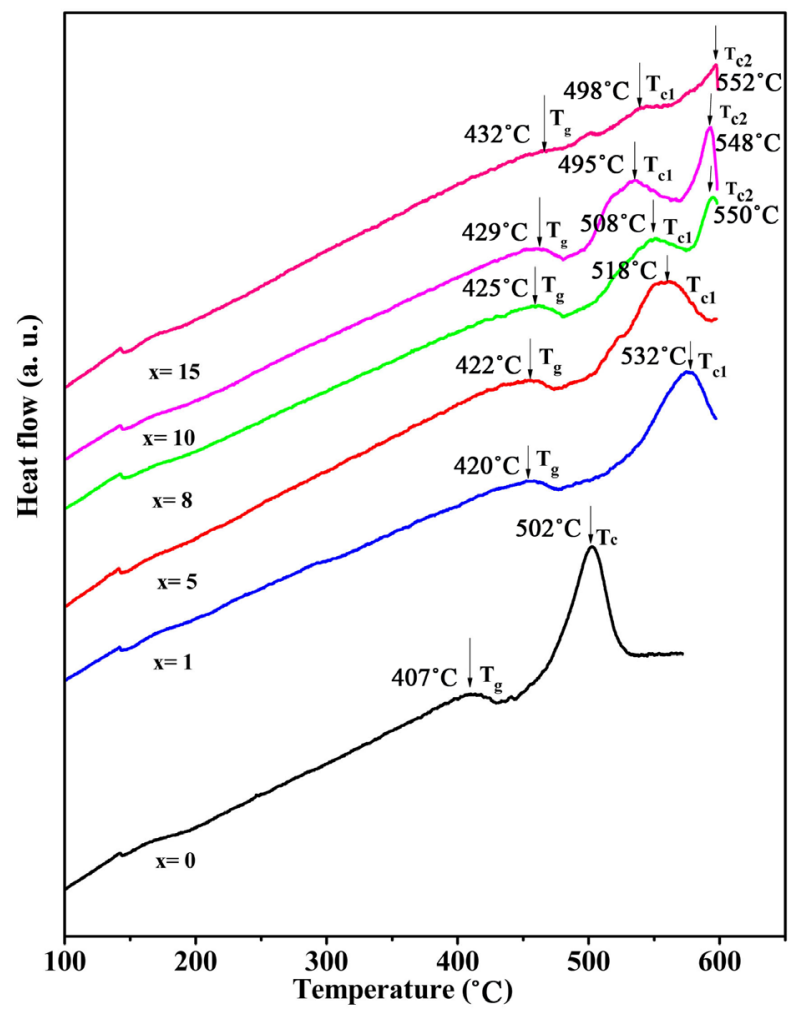

Figure 3. DSC curves of the studied glasses.

endothermic peak $\left(T_{g}\right)$ and an exothermic peak $\left(T_{c 1}\right)$. However, the glasses with the compositions $(\mathrm{x}=8,10$ and 15$)$ show two exothermic peaks $\left(T_{c 1}, T_{c 2}\right)$. The values of $T_{g}, T_{c 1}$ and $T_{c 2}$ for the prepared glasses are summarized in Table 1. The substitution $\mathrm{Li}_{2} \mathrm{WO}_{4}$ with $\mathrm{Fe}_{2} \mathrm{O}_{3}$ increases the glass transition temperature $\left(T_{g}\right)$ from $T_{g}=407^{\circ} \mathrm{C} \pm 2^{\circ} \mathrm{C}$ to $T_{g}=432^{\circ} \mathrm{C} \pm 2^{\circ} \mathrm{C}$.

From the analysis of Figure 4 and data of Table 1, one can see that $T_{g}$ increases with increasing Fe/P ratio. The increase of $T_{g}$ reflects an increase of the glass viscosity as well as the formation of stronger bonding in the glass such as P-O-Fe bonds. The increase of $T_{g}$ with iron content can also be associated to the reticulation effect of iron in the network. If such assumption is true one can expect an increase of the oxygen packing density (OPD) when the iron ratio increases. However, an opposite trend for (OPD) is obtained (Figure 4). Therefore, the most prominent reason for increasing $T_{g}$ with iron oxide is the formation of strong bonds in the glass network.

\section{Infrared Spectroscopy}

The structure approach of the prepared glasses has been investigated by using FTIR spectroscopy in frequency range $400-1400 \mathrm{~cm}^{-1}$. Such study allows us to check the phosphate units and other vibrational modes present in the network. The obtained IR spectra of the glasses are shown in Figure 5. The assignment of the different bands is realized according to previous literature data [17] [18]. The band positions and their assignments are gathered in Table 2 . 


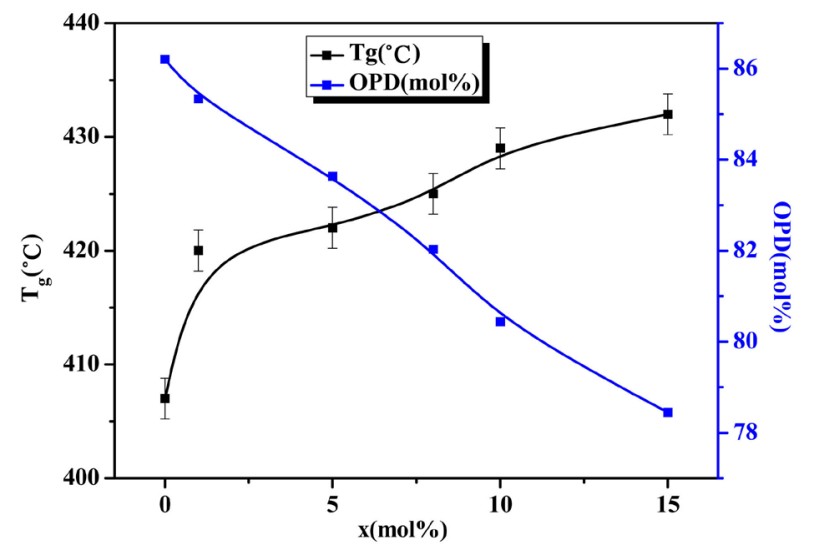

Figure 4. Glass transition temperature $\left(T_{g}\right)$ and oxygen packing density (OPD) of the studied glasses.

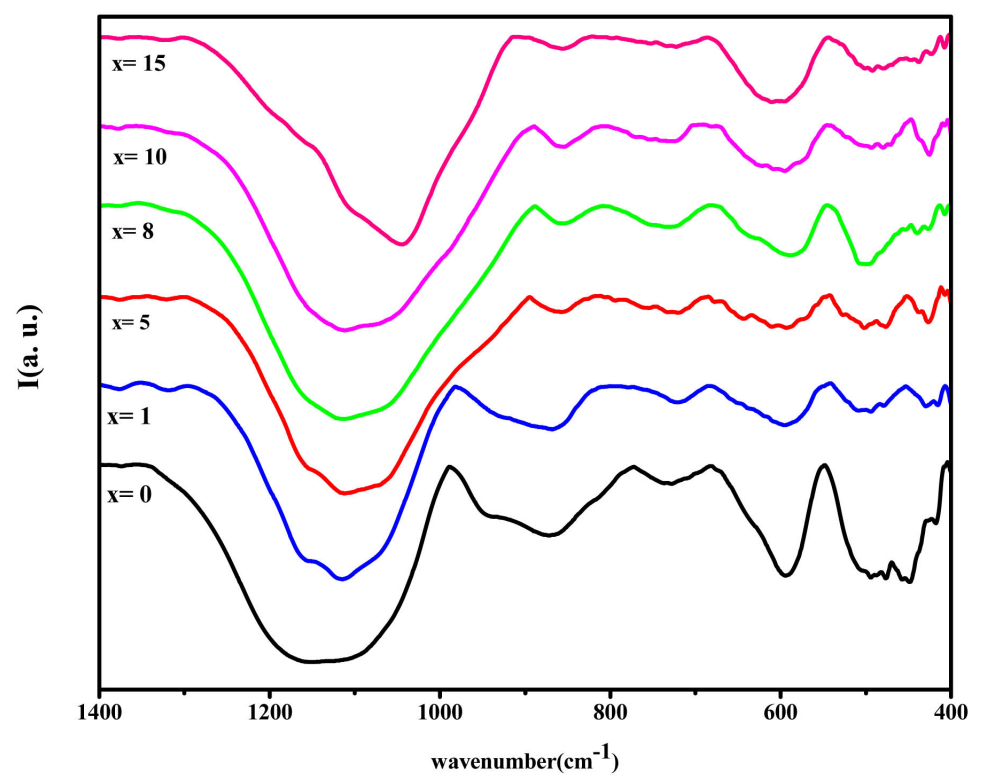

Figure 5. Infrared spectra of the studied glasses.

Table 2. IR band assignments in the $400-1400 \mathrm{~cm}^{-1}$ range frequency for the studied phosphate glasses.

\begin{tabular}{cc}
\hline Position of band $\left(\mathrm{cm}^{-1}\right)$ & Band assignment \\
\hline 1240 & $v_{\mathrm{as}}(\mathrm{P}=\mathrm{O}) / v_{\mathrm{as}}\left(\mathrm{PO}_{2}^{-}\right)$ \\
1160 & $v_{\mathrm{s}}\left(\mathrm{PO}_{2}\right)^{-}$ \\
1100 & $v_{\mathrm{as}}\left(\mathrm{PO}_{3}\right)^{2-}$ \\
$935-920$ & $v_{a s}(\mathrm{P}-\mathrm{O}-\mathrm{P}) / v_{a s}(\mathrm{P}-\mathrm{O}-\mathrm{M})(\mathrm{M}=\mathrm{W} \cdot \mathrm{Fe})$ \\
$880-870$ & $\mathrm{MO}_{6}(\mathrm{M}=\mathrm{W} \cdot \mathrm{Fe})$ \\
735 & $v_{s}(\mathrm{P}-\mathrm{O}-\mathrm{P})$ \\
725 & $(\mathrm{FeO})$ \\
$640-630$ & $v_{\mathrm{s}}(\mathrm{M}-\mathrm{O}-\mathrm{M})(\mathrm{M}=\mathrm{W} \cdot \mathrm{Fe})$ \\
$500-425$ & $\delta(\mathrm{O}-\mathrm{P}-\mathrm{O})$ and translation of cations
\end{tabular}


The principal bands are observed in the range 950 to $1220 \mathrm{~cm}^{-1}$. They correspond to symmetric and asymmetric stretching modes of non-bridging oxygen on different $\mathrm{P}$-tetrahedra. The band $v_{\mathrm{as}}\left(\mathrm{PO}_{2}\right)^{-}\left(\mathrm{Q}^{2}\right)$ in metaphosphate is located in the range $1220-1200 \mathrm{~cm}^{-1}, v_{\mathrm{as}}\left(\mathrm{PO}_{3}\right)^{2-}\left(\mathrm{Q}^{1}\right)$ of pyrophosphate groups and the mode vibration of isolated orthophosphate groups $\mathrm{PO}_{4}^{3-}\left(\mathrm{Q}^{0}\right)$ are situated in the range $1040-1000 \mathrm{~cm}^{-1}$. The band at $970-930 \mathrm{~cm}^{-1}$ is assigned to the asymmetric vibrations $v_{\mathrm{as}}(\mathrm{P}-\mathrm{O}-\mathrm{P})$ and/or $v_{\mathrm{as}}(\mathrm{P}-\mathrm{O}-\mathrm{M})(\mathrm{M}=\mathrm{W}, \mathrm{Fe})$. The band at 730 $720 \mathrm{~cm}^{-1}$ is attributed to the symmetric stretching modes $v_{\mathrm{s}}(\mathrm{P}-\mathrm{O}-\mathrm{P})$. The broad band in the range $500-480 \mathrm{~cm}^{-1}$ belongs to bending vibrations of basic structural units of phosphate glasses. The substitution of $\mathrm{Li}_{2} \mathrm{WO}_{4}$ by $\mathrm{Fe}_{2} \mathrm{O}_{3}$ leads to changing in frequency and intensity of some bands. With the increase of the iron content in the glasses, it is observed that the intensity of the band associated to $\mathrm{Q}^{1}$ species increases. Also, the intensity of $\mathrm{Q}^{0}$ species $\left(1040-1000 \mathrm{~cm}^{-1}\right)$ increases with increasing the iron content. It seems that the iron oxide depolymerizes the network and its content increasing induces the formation of pyrophosphate and orthophosphate structural units in the network.

\section{Chemical Durability}

Generally, the dissolution process of the glasses depends on several parameters such as surface of the glass, layer formation, and solution chemistry. The dissolution behavior of the glass is controlled by the reaction of the glass network and the type of ions existing in the solution [19].

\subsection{Weight Loss}

Figure 6 shows the weight loss as a function of time for the $20 \mathrm{Li}_{2} \mathrm{O}-(50-$ $\mathrm{x}) \mathrm{Li}_{2} \mathrm{WO}_{4}-\mathrm{xFe}_{2} \mathrm{O}_{3}-30 \mathrm{P}_{2} \mathrm{O}_{5}$ glasses $(0 \leq \mathrm{x} \leq 15)$. When the content of $\mathrm{Fe}_{2} \mathrm{O}_{3}$ is increased from $\mathrm{x}=0 \mathrm{~mol} \%$ to $\mathrm{x}=15 \mathrm{~mol} \%$, we can differentiate two stages: 1 ) for $t$ $<100 \mathrm{~h}$, the dissolution is almost linear. The initial corrosion rate is also

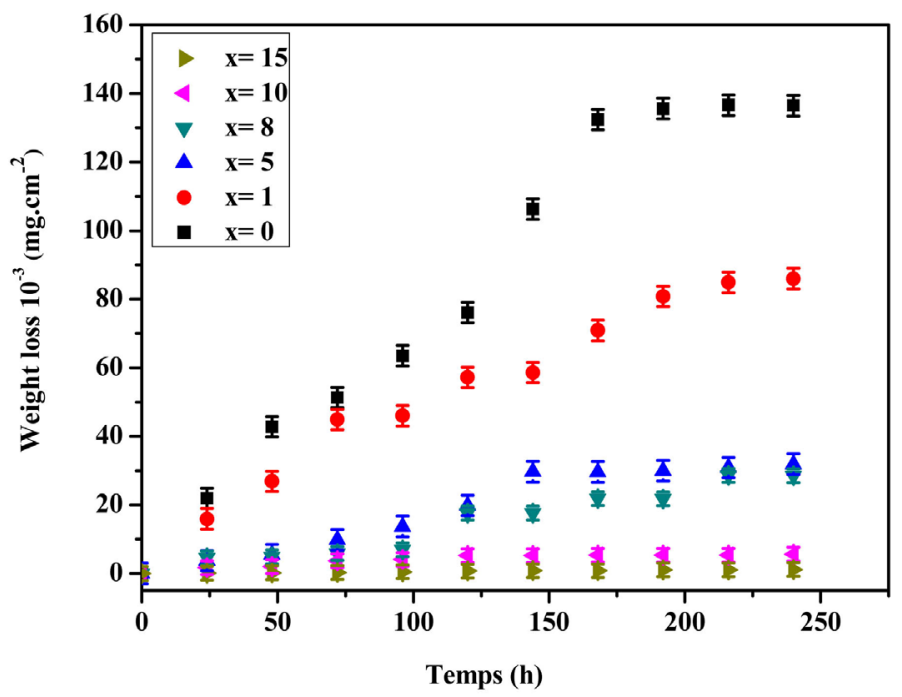

Figure 6. Evolution of the weight loss of the glasses as a function of time (h). 
determined; 2) for $100 \mathrm{~h}<t<250 \mathrm{~h}$, there is a marked slowdown in dissolution. Indeed, $\mathrm{Li}_{2} \mathrm{WO}_{4}$ substitution by $\mathrm{Fe}_{2} \mathrm{O}_{3}$ has observable effect on the dissolution behavior of synthesized glasses. The temporal evolution of the dissolution shows that the glass of composition $(\mathrm{x}=0)$ is characterized by a faster initial dissolution than that of the other glasses $(\mathrm{x}=1$ or $5 \mathrm{~mol} \%)$. The solubility of the glasses studied depends on the degree of substitution of $\mathrm{Li}_{2} \mathrm{WO}_{4}$ by $\mathrm{Fe}_{2} \mathrm{O}_{3}$. It can be said that $\mathrm{Fe}_{2} \mathrm{O}_{3}$ leads to the improvement of the chemical durability of the network by the formation of P-O-Fe type bonds, which have been identified by the use of infrared spectroscopy of $\mathrm{Fe}_{2} \mathrm{O}_{3}$-containing glasses. These results are consistent with thermal analysis which showed that the introduction of $\mathrm{Fe}_{2} \mathrm{O}_{3}$ into the phosphate glass network makes the glass matrix harder. The correlation between the results of the dissolution and the results of the thermal analysis showed that the introduction of $\mathrm{Fe}_{2} \mathrm{O}_{3}$ in the vitreous network leads to the reinforcement of the chains constituting the vitreous matrix of the glass prepared [20].

The enhancement of the chemical durability of the glasses with high iron content could be due to the low rate of glass surface hydration. Bunker et al. developed the general description for the dissolution reactions between phosphate glasses and water [21]. The first stage of dissolution is controlled by diffusion, including penetration of $\mathrm{H}_{2} \mathrm{O}$ into the glass network and diffusion of ions through the developing hydrated layer back into solution. Water hydrates the phosphate anions by reacting with the metal (alkali, Fe)-O-P bonds that link neighboring $\mathrm{P}$-anions [22]. At longer times, linear reaction kinetic dominates as the hydrated metals and phosphate anions are released into solution.

\section{2. $\mathrm{pH}$ Variation}

From the measurements of the $\mathrm{pH}$ of the leachate solution (Figure 7), it is observed that $\mathrm{pH}$ values decrease with time. For the glasses without $(\mathrm{x}=0)$ or with lower iron content the measured $\mathrm{pH}$ corresponds to acidic solutions. From the analysis of Figure 7 we observed that the $\mathrm{pH}$ values of the leachates show two phases: 1) before $48 \mathrm{~h}$ there is a sudden alteration or the thermodynamic imbalance between the glass and the altering solution is great which creates a sudden decrease in $\mathrm{pH} ; 2$ ) after $48 \mathrm{~h}$, a phase of slowing down of corrosion which is associated with the saturation of the altering solution which leads to the formation of a protective layer against the diffusion through the surface of the glass.

This $\mathrm{pH}$ variation depends on the chemical composition of the glass. We can say that the alkaline ions and the phosphate ions of the glass surface were released into the solution. This ion exchange plays a major role in defining the acid-base character of the solution. Indeed, the decrease of the $\mathrm{pH}$ can be attributed to the disintegration of the phosphatic entities towards the altering solution and the possibility of formation of phosphoric acid controlled by the $\mathrm{H}_{2} \mathrm{PO}_{4}^{-}$entities. These entities are obtained from the dissociation of orthophosphoric acid in water [23] [24] [25] [26]:

$$
\mathrm{H}_{3} \mathrm{PO}_{4}+\mathrm{H}_{2} \mathrm{O} \leftrightarrow \mathrm{H}_{2} \mathrm{PO}_{4}^{-}+\mathrm{H}_{3} \mathrm{O}^{+}\left(K_{1}=7.1 \times 10^{-3}\right)
$$




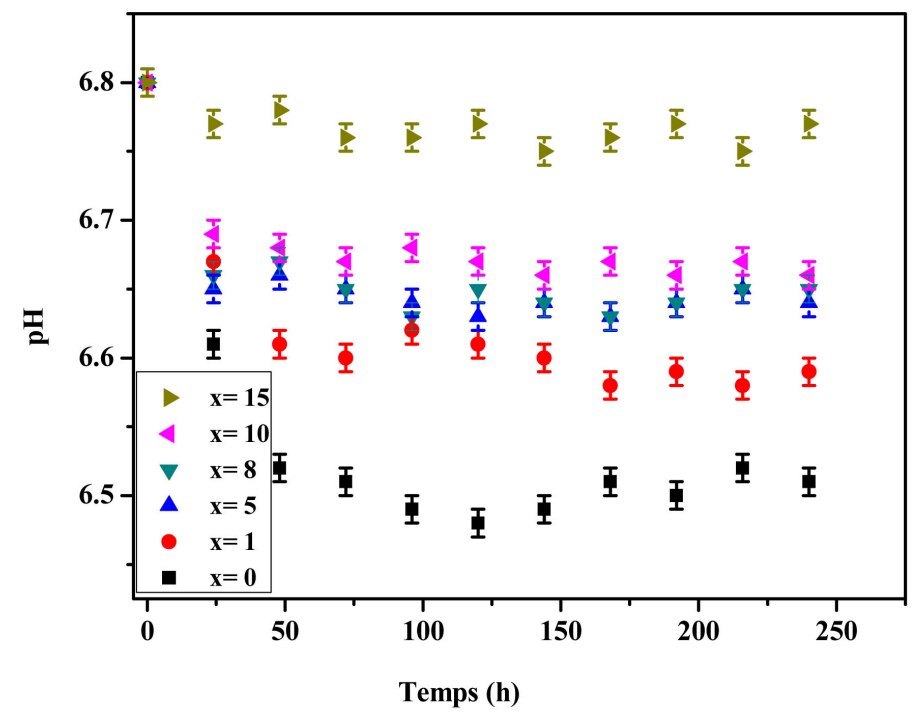

Figure 7. Variation of the $\mathrm{pH}$ versus time for the glasses.

$$
\begin{gathered}
\mathrm{H}_{2} \mathrm{PO}_{4}^{-}+\mathrm{H}_{2} \mathrm{O} \leftrightarrow \mathrm{HPO}_{4}^{2-}+\mathrm{H}_{3} \mathrm{O}^{+}\left(K_{2}=6.3 \times 10^{-8}\right) \\
\mathrm{HPO}_{4}^{2-}+\mathrm{H}_{2} \mathrm{O} \leftrightarrow \mathrm{PO}_{4}^{3-}+\mathrm{H}_{3} \mathrm{O}^{+}\left(K_{3}=4.4 \times 10^{-13}\right)
\end{gathered}
$$

The dissociation constants allowed us to conclude that the dihydrogen phosphate ions $\mathrm{H}_{2} \mathrm{PO}_{4}^{-}$in the water are much more abundant compared to the monohydrogen phosphate ions $\mathrm{HPO}_{4}^{2-}$ and phosphate ions $\mathrm{PO}_{4}^{3-}$.

\subsection{Electrical Properties}

The conductivity for the prepared glasses is determined according to Equation (1):

$$
\sigma=(t / a) *\left(1 / Z^{\prime}\right)
$$

where " $\sigma$ " is the conductivity, " $t$ " is the thickness, " $a$ " is the cross-section area of the pellet and " $Z$ '” is the bulk resistance.

Figure 8 shows the temperature dependence of the conductivity for the studied glasses. It increases with increasing temperature and follows an Arrhenius law (2):

$$
\sigma . T=\sigma_{0} \exp \left(-E_{a} / k_{B} T\right)
$$

where, $E_{a}$ is the activation energy, $\sigma_{0}$ is the pre-exponential term and $k_{B}$ is the Boltzmann constant.

These electrical parameters are determined (Table 3 ). The conductivity of the glasses depends on the composition of iron oxide. It increases with $\mathrm{Fe}_{2} \mathrm{O}_{3}$ content up to $(\mathrm{x}=10)$, then it decreases. The variation of the activation energy follows an opposite trend to that of the conductivity. It seems that up to $(x=10)$ the mobility is the more influencing parameter since the concentration of lithium ion decreases with $\mathrm{Fe}_{2} \mathrm{O}_{3}$ content. However, when the ratio of iron reaches $\mathrm{x}=15 \mathrm{~mol} \%$ the decrease of the conductivity may be due to the low lithium content in the glasses. 


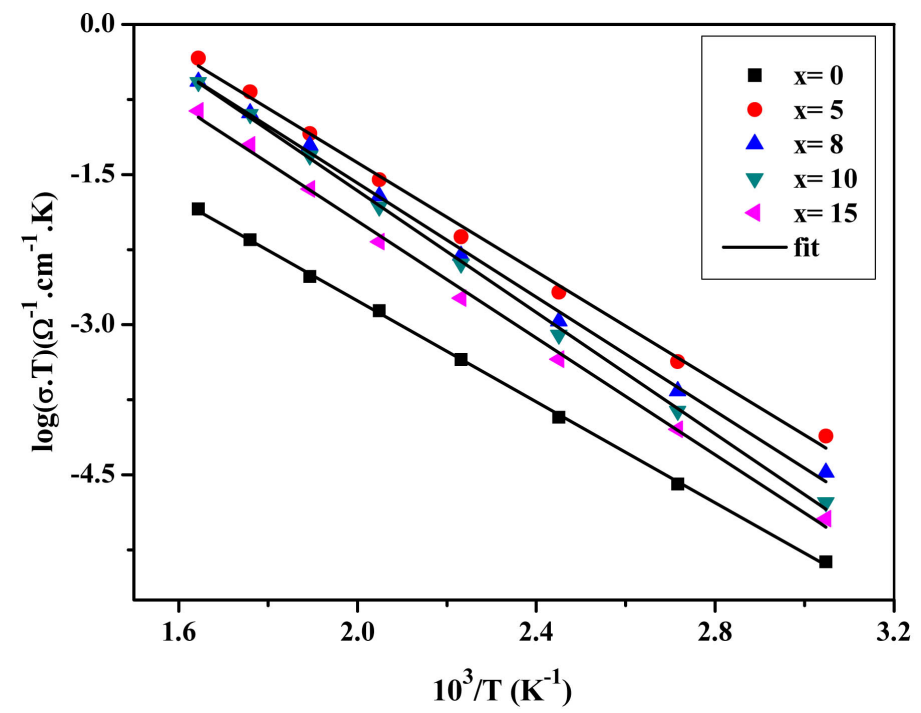

Figure $8 . \log \left(\sigma_{d c} \cdot T\right)$ vs $1000 / T$ plots for the glasses.

Table 3. Electrical parameters of the studied glasses.

\begin{tabular}{ccccc}
\hline $\mathbf{x}(\mathrm{mol} \%)$ & $\log \sigma_{\mathrm{dc}} .408\left(\Omega^{-1} \cdot \mathrm{cm}^{-1} \cdot \mathrm{K}\right)$ & $\mathrm{E}_{\mathrm{a}}(\mathrm{eV})$ & $\mathrm{E}_{\mathrm{f}}(\mathrm{eV})$ & $\beta$ \\
\hline 0 & -5.16 & 0.50 & 0.50 & 0.38 \\
5 & -5.93 & 0.54 & 0.54 & 0.88 \\
8 & -6.23 & 0.56 & 0.56 & 0.86 \\
10 & -6.43 & 0.60 & 0.60 & 0.76 \\
15 & -6.13 & 0.58 & 0.58 & 0.88 \\
\hline
\end{tabular}

The obtained data of electrical measurements are analyzed by the modulus formalism $\left(M=M^{\prime}+i M^{\prime \prime}\right)$. The real and imaginary parts of $(\mathrm{M})$ are calculated from the measured impedance data using Equations (3) and (4):

$$
\begin{aligned}
& M^{\prime}=\omega C_{0} Z^{\prime \prime} \\
& M^{\prime \prime}=\omega C_{0} Z^{\prime}
\end{aligned}
$$

where, $Z^{\prime}$ and $Z^{\prime \prime}$ are the real and imaginary parts of the impedance, respectively. $\omega$ is the angular frequency and $C_{0}$ is the vacuum capacitance of the cell.

Figure 9 shows the variation of $M^{\prime \prime} / M_{\max }^{\prime \prime}$ as a function of frequency in the range $\left(20 \mathrm{~Hz}-10^{6} \mathrm{~Hz}\right)$ at different temperatures for the prepared glasses $(\mathrm{x}=0$ and $\mathrm{x}=10$ ). These $M^{\prime \prime} / M_{\max }^{\prime \prime}$ spectra are slightly asymmetric suggesting that the relaxation present in the material was non-Debye. The maximum in the $M^{\prime \prime} / M_{\max }^{\prime \prime}$ peak shifts to higher frequency with increasing temperature. The shift in $M^{\prime \prime} / M_{\max }^{\prime \prime}$ peak maximum corresponds to the conductivity relaxation. This behavior suggests that the dielectric relaxation is thermally activated. The relaxation frequency $f_{p}$ of the charge carriers is determined from the maximum of $M^{\prime \prime} / M_{\max }^{\prime \prime}$ [27]. The variation of the determined peak frequency $\left(f_{p}\right)$ as a function of temperature is shown in Figure 10. From the analysis of this latter figure, it is observed that the frequency relaxation is thermally activated and 


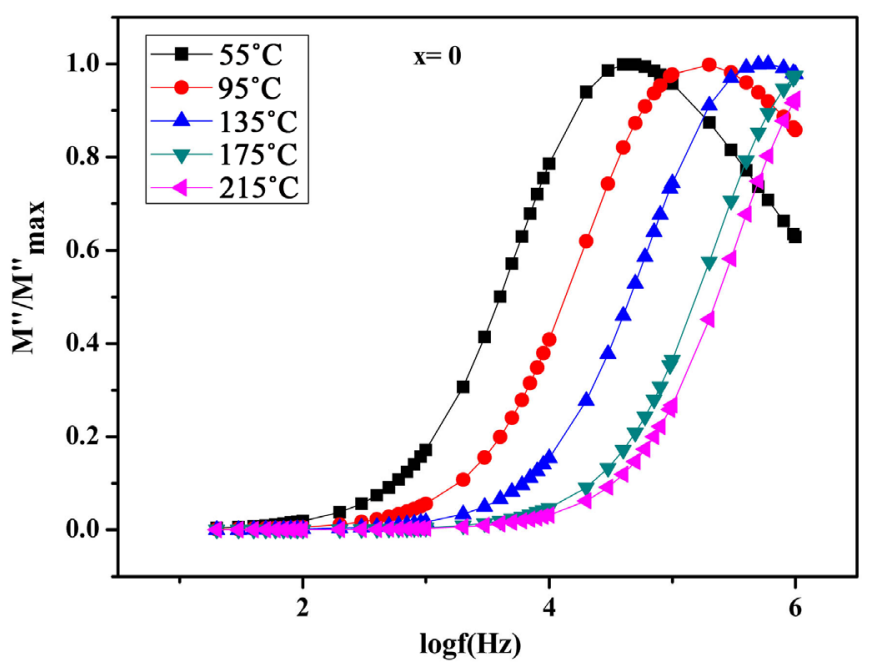

(a)

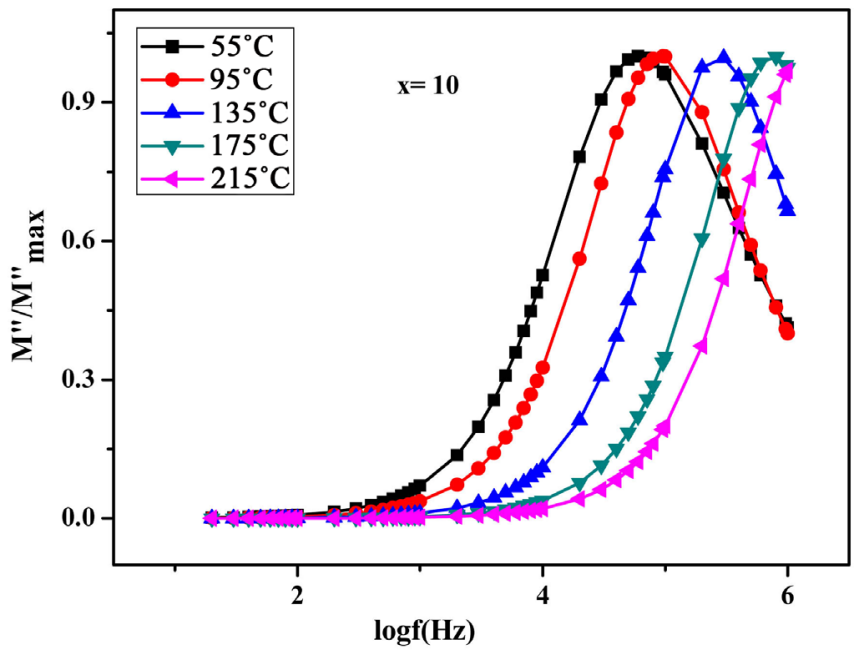

(b)

Figure 9. The frequency dependence of $M^{\prime \prime} / M_{\max }^{\prime \prime}$ for the glasses $(\mathrm{x}=0)$ and $(\mathrm{x}=10)$.

follows an Arrhenius behavior with activation energy $\left(E_{f}\right)$. In order to determine the mechanism of conduction, we plotted in the same figure the temperature dependence of the conductivity as shown in Figure 10 for the glasses ( $x=5$, and $\mathrm{x}=15)$. We observe that both lines are quasi-parallel and the activation energies issued from impedance $\left(E_{a}\right)$ and modulus $\left(E_{f}\right)$ spectra are very similar (Table 3 ). This result suggests that the electrical conductivity in the glasses under study is probably due to hopping mechanism [28].

The asymmetric nature of $M^{\prime \prime} / M_{\max }^{\prime \prime}$ spectra suggested that the relaxation behavior was non-Debye and could be characterized by the stretched exponent parameter $\beta<1$ [29]. For an ideal dielectric material, for which the dipole-dipole interaction is negligible, the value of $\beta$ is equal to unity $(\beta=1)$. The stretched exponent parameters, $\beta$, can be obtained from the peak relaxation frequency ( $\beta$ $=1.14 / \mathrm{FWHM})$, where (FWHM) is the width at half-maximum of $M^{\prime \prime}(f)$ curves. For each glass, it is found that the value of $\beta$ is independent of temperature and 


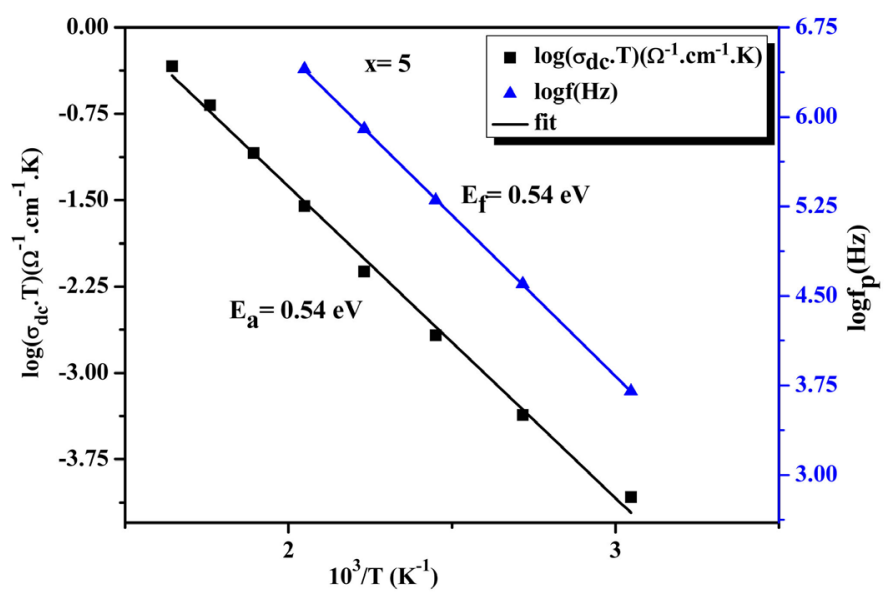

(a)

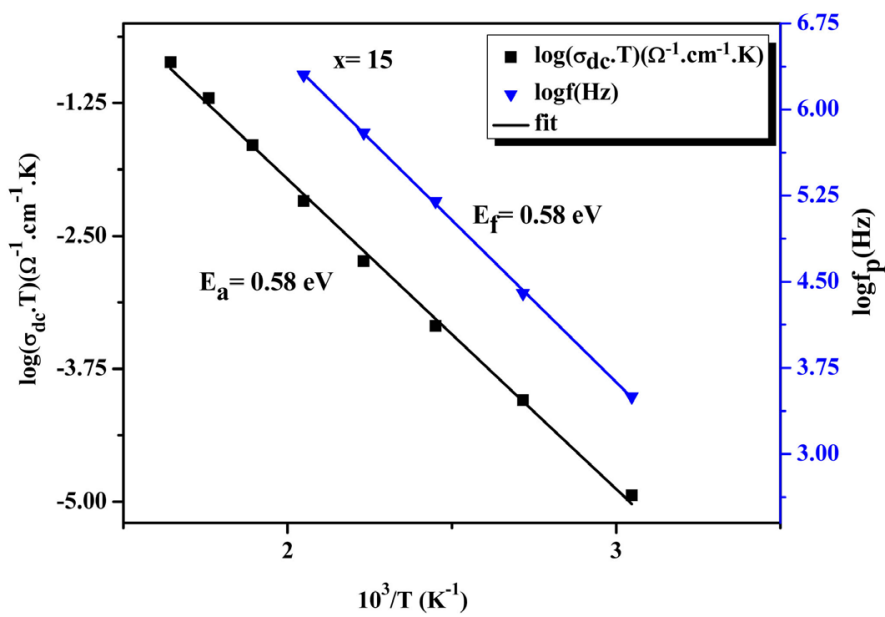

(b)

Figure 10. Temperature dependence of $\log \sigma_{d c} \cdot T$ and $\log f_{p}$ for the glasses $(\mathrm{x}=5)$ and $(\mathrm{x}=$ 15).

the obtained values of $\beta$ for all the compositions are regrouped in Table 3. The values of $\beta$ are found to be less than unity. This demonstrated the non-Debye nature of the dielectric relaxation inside the glasses.

The electrical impedance data are also analyzed by the dielectric formalism ( $\left.\varepsilon^{*}=\varepsilon^{\prime}-j \varepsilon^{\prime \prime}\right)$ by using the following Equation (5) [30]:

$$
\varepsilon^{*}(\omega)=\varepsilon^{\prime}(\omega)-j \varepsilon^{\prime \prime}(\omega)=1 /\left(j C_{0}\left(Z^{\prime}+j Z^{\prime \prime}\right)\right)
$$

where, $\varepsilon^{\prime}$ is the real part of the permittivity (resistive) and $\varepsilon^{\prime \prime}$ is the imaginary part of the permittivity (reactive), $C_{0}$ the capacitance of the empty cell. These parameters are determinate according to Equations (7) and (8) respectively:

$$
\begin{gathered}
\varepsilon^{\prime}=-Z^{\prime \prime} / \omega C_{0}\left(Z^{\prime 2}+Z^{\prime \prime 2}\right) \\
\varepsilon^{\prime \prime}=Z^{\prime} / \omega C_{0}\left(Z^{\prime 2}+Z^{\prime \prime 2}\right)
\end{gathered}
$$

The dielectric constant values measured from the impedance data are plotted as a function of frequency at different temperatures in Figure 11. It is observed 


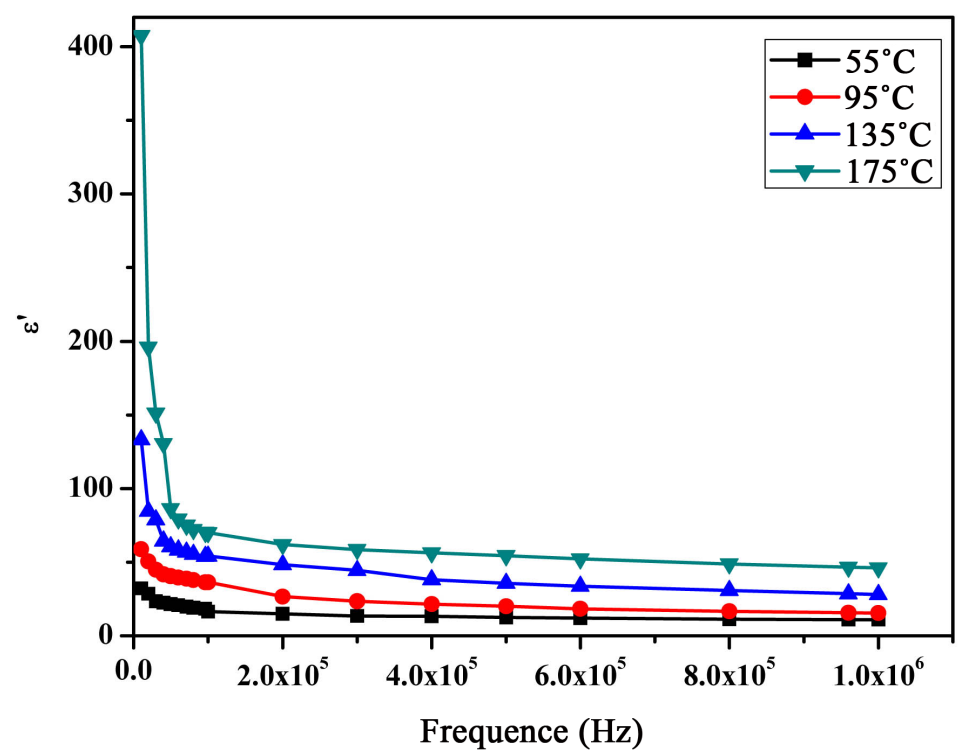

Figure 11. Variation of the permittivity as a function of the frequency for the glass $(\mathrm{x}=$ 5).

that the glasses showed high values of the permittivity at low frequency and high temperature. This can be explained on the basis of the polarization existing in the sample. The increased dielectric constant value at lower frequencies region is related to the contribution from space charge/interfacial polarization. Indeed, the higher $\varepsilon^{\prime}(\omega)$ values of these amorphous glasses at lower frequencies were explained by the presence of bulk interfacial. Interfacial contains defects such as dangling bonds, vacancies, and vacancy clusters. Thus, the space charges can move under the application of an external field and when they are trapped by the defects, lots of dipole moments (space charge polarization) are formed [31]. The increase in $\varepsilon^{\prime}(\omega)$ with temperature is due to the weakening of binding force between molecules/atoms with the increase in temperature, permitting the molecules/atoms to vibrate more and more which in turn increase the polarization, hence increase in the dielectric constant $\varepsilon^{\prime}(\omega)$ [32]. In addition, the decrease in $\varepsilon^{\prime}(\omega)$ with the frequency is explained by the decreasing number of dipoles which contribute to polarization. As a matter fact, the application of the electrical field with low frequency assists electron hopping between two different sites in the glasses. Whereas, at high frequency, the charge carriers will be unable to rotate with enough speed, so their oscillation is going to vanish [33].

\section{Conclusion}

The glasses inside the $20 \mathrm{Li}_{2} \mathrm{O}-(50-\mathrm{x}) \mathrm{Li}_{2} \mathrm{WO}_{4}-\mathrm{xFe}_{2} \mathrm{O}_{3}-30 \mathrm{P}_{2} \mathrm{O}_{5}$ system were prepared by melt-quenching method. The substitution of $\mathrm{Li}_{2} \mathrm{WO}_{4}$ by $\mathrm{Fe}_{2} \mathrm{O}_{3}$ increases the density and the glass transition temperature $T_{g}$. The analysis of the glasses by IR spectroscopy has revealed that the introduction of $\mathrm{Fe}_{2} \mathrm{O}_{3}$ content in the glasses transforms some metaphosphate groups $\left(\mathrm{Q}^{2}\right)$ to pyrophosphate $\left(\mathrm{Q}^{1}\right)$ and orthophosphate $\left(\mathrm{Q}^{0}\right)$ structural units. The formation of the Fe-O-P water-resist 
bonds in the glass network is highlighted and this iron bond-type improved their chemical durability. The electrical conductivity of the glasses is thermally activated and follows an Arrhenius behavior. The dielectric relaxation behavior inside the glasses is non-Debye.

\section{Acknowledgements}

The authors would like to thank CNRST and OCP for their financial support of this work (PPR project).

\section{Conflicts of Interest}

The authors declare no conflicts of interest regarding the publication of this paper.

\section{References}

[1] Bih, L., El Omari, M., Réau, J.M., Haddad, M., Boudlich, D., Yacoubi, A. and Nadiri, A. (2000) Electronic and Ionic Conductivity of Glasses Inside the $\mathrm{Li}_{2} \mathrm{O}-\mathrm{MoO}_{3}-\mathrm{P}_{2} \mathrm{O}_{5}$ System. Solid State Ionics, 132, 71-85. https://doi.org/10.1016/S0167-2738(00)00697-4

[2] Gowda, V.V. and Anavekar, R.V. (2005) Transport Properties of $\mathrm{Li}_{2} \mathrm{O}-\mathrm{MnO}_{2}-\mathrm{B}_{2} \mathrm{O}_{3}$ Glasses. Solid State Ionics, 176, 1393-1401. https://doi.org/10.1016/j.ssi.2005.04.002

[3] Salehizadeh, S.A., Melo, B.M.G., Freire, F.N.A., Valente, M.A. and Graça, M.P.F. (2016) Structural and Electrical Properties of $\mathrm{TeO}_{2}-\mathrm{V}_{2} \mathrm{O}_{5}-\mathrm{K}_{2} \mathrm{O}$ Glassy Systems. Journal of Non-Crystalline Solids, 443, 65-74. https://doi.org/10.1016/j.jnoncrysol.2016.03.012

[4] Ishiyama, T., Suzuki, S., Nishii, J., Yamashita, T., Kawazoe, H. and Omata, T. (2014) Proton Conducting Tungsten Phosphate Glass and Its Application in Intermediate Temperature Fuel Cells. Solid State Ionics, 262, 856-859. https://doi.org/10.1016/j.ssi.2013.10.055

[5] Es-Soufi, H., Bih, L., Manoun, B., Mezzane, D. and Lazor, P. (2016) Some Physical Properties of the Glasses within the $\mathrm{Li}_{2} \mathrm{O}-\mathrm{Li}_{2} \mathrm{WO}_{4}-\mathrm{TiO}_{2}-\mathrm{P}_{2} \mathrm{O}_{5}$ System. 1 st International Symposium on Dielectric Materials and Applications, Kenitra, 4-6 May 2016, 266-269.

[6] Ganguli, M. and Rao, K.J. (1999) Structural Role of $\mathrm{PbO}$ in $\mathrm{Li}_{2} \mathrm{O}-\mathrm{PbO}-\mathrm{B}_{2} \mathrm{O}_{3}$ Glasses. Journal of Solid State Chemistry, 145, 65-76. https://doi.org/10.1006/jssc.1999.8221

[7] Sales, B.C., Abraham, M.M., Bates, J.B. and Boatner, L.A. (1985) Structural Properties of Lead-Iron Phosphate Glasses. Journal of Non-Crystalline Solids, 71, 103-112. https://doi.org/10.1016/0022-3093(85)90279-0

[8] Pascuta, P., Borodi, G., Popa, A., Dan, V. and Culea, E. (2010) Influence of Iron Ions on the Structural and Magnetic Properties of Some Zinc-Phosphate Glasses. Materials Chemistry and Physics, 123, 767-771.

https://doi.org/10.1016/j.matchemphys.2010.05.056

[9] Donald, I.W., Metcalfe, B.L., Fong, S.K., Gerrard, L.A., Strachan, D.M. and Scheele, R.D. (2007) A Glass-Encapsulated Calcium Phosphate Waste Form for the Immobilization of Actinide-, Fluoride-, and Chloride-Containing Radioactive Wastes from the Pyrochemical Reprocessing of Plutonium Metal. Journal of Nuclear Materials, 361, 78-93. https://doi.org/10.1016/j.jnucmat.2006.11.011

[10] Sales, B.C. and Boatner, L.A. (1984) Lead-Iron Phosphate Glass: A Stable Storage Medium for High-Level Nuclear Waste. Science, 226, 45-48. 
https://doi.org/10.1126/science.226.4670.45

[11] Peng, Y.B. and Day, D.E. (1991) High Thermal Expansion Phosphate Glasses. Part 1.

[12] Greaves, G.N., Gurman, S.J., Gladden, L.F., Spence, C.A., Cox, P., Sales, B.C., Jenkins, R.N., et al. (1988) A Structural Basis for the Corrosion Resistance of Lead-Iron-Phosphate Glasses: An X-Ray Absorption Spectroscopy Study. Philosophical Magazine B, 58, 271-283. https://doi.org/10.1080/13642818808208469

[13] Yu, X., Day, D.E., Long, G.J. and Brow, R.K. (1997) Properties and Structure of Sodium-Iron Phosphate Glasses. Journal of Non-Crystalline Solids, 215, 21-31. https://doi.org/10.1016/S0022-3093(97)00022-7

[14] Nakata, S., Togashi, T., Honma, T. and Komatsu, T. (2016) Cathode Properties of Sodium Iron Phosphate Glass for Sodium Ion Batteries. Journal of Non-Crystalline Solids, 450, 109-115. https://doi.org/10.1016/j.jnoncrysol.2016.08.005

[15] Moustafa, Y.M., El-Egili, K., Doweidar, H. and Abbas, I. (2004) Structure and Electric Conduction of $\mathrm{Fe}_{2} \mathrm{O}_{3}-\mathrm{P}_{2} \mathrm{O}_{5}$ Glasses. Physica B: Condensed Matter, 353, 82-91. https://doi.org/10.1016/j.physb.2004.09.004

[16] Es-Soufi, H., Bih, L., Manoun, B. and Lazor, P. (2017) Structure, Thermal Analysis and Optical Properties of Lithium Tungsten-Titanophosphate Glasses. Journal of Non-Crystalline Solids, 463, 12-18. https://doi.org/10.1016/j.jnoncrysol.2017.02.013

[17] Kim, C.W., Ray, C.S., Zhu, D., Day, D.E., Gombert, D., Aloy, A., Karabulut, M., et al. (2003) Chemically Durable Iron Phosphate Glasses for Vitrifying Sodium Bearing Waste (SBW) Using Conventional and Cold Crucible Induction Melting (CCIM) Techniques. Journal of Nuclear Materials, 322, 152-164. https://doi.org/10.1016/S0022-3115(03)00325-8

[18] Joseph, K., Ravindran, T.R., Sudha, R. and Asuvathraman, R. (2019) $\mathrm{BaO}-\mathrm{Fe}_{2} \mathrm{O}_{3}-\mathrm{P}_{2} \mathrm{O}_{5}$ Glasses: Understanding the Thermal Stability. Journal of Nuclear Materials, 517, 106-112. https://doi.org/10.1016/j.jnucmat.2019.01.046

[19] Clark, D.E. and Zoitos, B.K. (1992) Corrosion of Glass, Ceramics and Ceramic Superconductors: Principles, Testing, Characterization and Applications.

[20] Li, X., Lu, A. and Yang, H. (2014) Structure of $\mathrm{ZnO}-\mathrm{Fe}_{2} \mathrm{O}_{3}-\mathrm{P}_{2} \mathrm{O}_{5}$ Glasses Probed by Raman and IR Spectroscopy. Journal of Non-Crystalline Solids, 389, 21-27. https://doi.org/10.1016/j.jnoncrysol.2014.01.051

[21] Reis, S.T., Moguš-Milanković, A., Ličina, V., Yang, J.B., Karabulut, M., Day, D.E. and Brow, R.K. (2007) Iron Redox Equilibrium, Structure and Properties of Zinc Iron Phosphate Glasses. Journal of Non-Crystalline Solids, 353, 151-158. https://doi.org/10.1016/j.jnoncrysol.2006.10.002

[22] Grishin, S.I., Bigham, J.M. and Tuovinen, O.H. (1988) Characterization of Jarosite Formed upon Bacterial Oxidation of Ferrous Sulfate in a Packed-Bed Reactor. Applied and Environmental Microbiology, 54, 3101-3106.

[23] Ma, L., Brow, R.K. and Schlesinger, M.E. (2017) Dissolution Behavior of $\mathrm{Na}_{2} \mathrm{O}-\mathrm{FeO}-\mathrm{Fe}_{2} \mathrm{O}_{3}-\mathrm{P}_{2} \mathrm{O}_{5}$ Glasses. Journal of Non-Crystalline Solids, 463, 90-101. https://doi.org/10.1016/j.jnoncrysol.2017.02.022

[24] Li, X., Xiao, Z., Luo, M., Dong, X., Du, T. and Wang, Y. (2017) Low Melting Glasses in $\mathrm{ZnO}-\mathrm{Fe}_{2} \mathrm{O}_{3}-\mathrm{P}_{2} \mathrm{O}_{5}$ System with High Chemical Durability and Thermal Stability for Sealing or Waste Immobilization. Journal of Non-Crystalline Solids, 469, 62-69. https://doi.org/10.1016/j.jnoncrysol.2017.04.023

[25] Ma, L., Brow, R.K., Ghussn, L. and Schlesinger, M.E. (2015) Thermal Stability of $\mathrm{Na}_{2} \mathrm{O}-\mathrm{FeO}-\mathrm{Fe}_{2} \mathrm{O}_{3}-\mathrm{P}_{2} \mathrm{O}_{5}$ Glasses. Journal of Non-Crystalline Solids, 409, 131-138. 
https://doi.org/10.1016/j.jnoncrysol.2014.11.019

[26] Poluektov, P.P., Schmidt, O.V., Kascheev, V.A. and Ojovan, M.I. (2017) Modelling Aqueous Corrosion of Nuclear Waste Phosphate Glass. Journal of Nuclear Materials, 484, 357-366. https://doi.org/10.1016/j.jnucmat.2016.10.033

[27] Ganguly, P. and Jha, A.K. (2010) Impedance Spectroscopy Analysis of $\mathrm{Ba}_{5} \mathrm{NdTi}_{3} \mathrm{Nb}_{7} \mathrm{O}_{30}$ Ferroelectric Ceramic. Physica B: Condensed Matter, 405, 3154-3158. https://doi.org/10.1016/j.physb.2010.04.035

[28] Bahgat, A.A. (1998) Study of Dielectric Relaxation in Na-Doped Bi-Pb-Sr-Ca-Cu-O Glasses. Journal of Non-Crystalline Solids, 226, 155-161.

https://doi.org/10.1016/S0022-3093(97)00482-1

[29] Bhat, M.H., Ganguli, M. and Rao, K.J. (2003) Conductivity Studies in SnO-NaPO Glasses. Bulletin of Materials Science, 26, 407-413. https://doi.org/10.1007/BF02711185

[30] Raja, V., Sharma, A.K. and Rao, V.N. (2004) Impedance Spectroscopic and Dielectric Analysis of PMMA $\square$ CO $\square$ P4VPNO Polymer Films. Materials Letters, 58, 3242-3247. https://doi.org/10.1016/j.matlet.2004.05.061

[31] Bahgat, A.A. and Abou-Zeid, Y.M. (2001) Mixed Alkali Effect in the $\mathrm{K}_{2} \mathrm{O}-\mathrm{Na}_{2} \mathrm{O}-\mathrm{TeO}_{2}$ Glass System. Physics and Chemistry of Glasses, 42, 361-370.

[32] Brahma, S., Choudhary, R.N.P. and Thakur, A.K. (2005) AC Impedance Analysis of $\mathrm{LaLiMo}_{2} \mathrm{O}_{8}$ Electroceramics. Physica B: Condensed Matter, 355, 188-201. https://doi.org/10.1016/j.physb.2004.10.091

[33] Affleck, L. and Leach, C. (2005) Microstructures of $\mathrm{BaTiO}_{3}$ Based PTC Thermistors with $\mathrm{Ca}, \mathrm{Sr}$ and $\mathrm{Pb}$ Additions. Journal of the European Ceramic Society, 25, 3017-3020. https://doi.org/10.1016/j.jeurceramsoc.2005.03.178 